\title{
Sports Metaphors in American Political Discourse
}

\author{
Mariam Askarian, Hovhannes Vanesyan \\ Yerevan State University
}

\begin{abstract}
In cognitive linguistics, conceptual metaphor refers to the understanding of an idea in terms of another familiar object. As conceptual metaphors are great persuasive means due to their ability to make unfamiliar things familiar, we have analyzed transcripts of recent political speeches with a special reference to presidential campaign speeches (2016-2019). It should be noted that the usage of conceptual metaphors is strictly linked to cultural patterns, i.e. Asian people tend to use conceptual metaphors of eating or family, while Western politicians tend to rely on sport, driving or war metaphors. The thing is that they consciously, subconsciously or even unconsciously view their lives as a race, a game or a battle. Our analysis is based on Western presidential campaign speeches. As an outcome of our analysis we wanted to reveal and elucidate that particular link between culture and cognitive linguistics.
\end{abstract}

Key words: cognitive linguistics, conceptual metaphors, culture, Western politicians, presidential campaign.

\section{Introduction}

Since sports metaphors are so popular in American English, we can see that in the American conceptual system, sports, business and politics are always combined. American people have an obsession with sports. People fuse politics and sports, showing people's perception of life as sports, without being aware of it. We can use Lakoff and Johnson's (1980:102) words to demonstrate the reason: "Our conceptual system is not something we are normally aware of. In most of the little things we do every day, we simply think and act more or less automatically along certain lines. Just what these lines are is by no means 
obvious. One way to find out is by looking at language. Since communication is based on the same conceptual system as we use in thinking and acting, language is an important source of evidence for what that system is like".

We may ask how the connection between politics and sports contributes to Americans' conceptual combination of the two domains. Since the United States is a nation with advanced democracy, everyone is encouraged to participate in governing, so politics is widely tackled by ordinary Americans. Only sports can compete with politics in terms of popularity and the extent and level of participation. Most people agree that American sports, especially professional sports, are the products of industrialization and sports have in turn strengthened the political "industry". Politics and sports are constantly promoted and benefit from each other. Besides, sports are a good way to promote national pride and patriotism. There's no wonder that lots of politicians turn to sports for various political purposes. Politics and sports are conceptually combined and the image of politicians and that of sports stars are prone to merge. People hope their sports stars become politicians and politicians are good at sports. Hence, in the government, there are quite a few politicians who were professional players. American children are taught to possess the spirit of competition, self-reliance, and entrepreneurship. This conception gradually forms the foundation of American way of life. People seek free competition and enterprise. That is why, in the public discourse, sports and politics always interact and many politicians often unconsciously treat politics like sports. We can say that American politics, in a sense, resembles a sports game. Due to the high frequency of usage of sports metaphors, American politics and politics in general, can be clearly depicted as a contest between two opponents.

\section{Sports Metaphors in American Politics}

The foundations of the cognitive theory of metaphor were laid down by George Lakoff and Mark Johnson (1980) in their influential work Metaphors We Live By. In this book, they developed a new theory that has become known as the cognitive view of metaphor. Some years later, Lakoff (1993) renamed it 
and referred to it as the contemporary theory of metaphor. Their key argument of the cognitive theory of metaphor is that metaphor forms an inherent part of our conceptual system - in their words, "our ordinary conceptual system, in terms of which we both think and act, is fundamentally metaphorical in nature" (Lakoff and Johnson 1980:26). Although the cognitive theory of metaphor tends to be described as radically new, the cognitive dimension of metaphor had been recognized by previous scholars. One of which, the interaction theory, viewed metaphor as a mental process, and even before that a number of philosophers, including John Locke, Giambattista Vico, and Immanuel Kant, had discussed the cognitive implications of metaphor (Semino 2008:13). According to this new perspective, the metaphor is defined as a cognitive mechanism whereby one conceptual domain is partially mapped onto a different conceptual domain, the second domain being partially understood in terms of the first one: "the essence of metaphor is understanding and experiencing one kind of thing in terms of another." (Lakoff and Johnson 1980: 82). The domain that is mapped is called the source and the domain onto which it is mapped is called the target. Sometimes, we find people unconsciously using metaphors in their public discourse. But, we feel puzzled by some of these metaphors, because we don't have the cultural knowledge behind them. Such a fascination and amazement have led researchers to a close examination of people's use of metaphor. Metaphors are widely used in human communication: ancient or contemporary, formal or informal. It is not just a matter of choice of the expressions nor is it merely a rhetorical device or a linguistic convenience in human communication. Metaphor participates fully in the process of knowledge and brings us to a new world. Culture is the symbol of civilization and the development of human language is closely related to diversities of culture. Different cultures may cause people to use different metaphors. For example, Western people tend to use obviously more sports, business, war and driving metaphors, because they consciously or unconsciously view their life as a sport and war; while the Chinese appear to use far more frequently family, eating and performing metaphors. So we can say language and culture are closely related. On most occasions, Western people are fond of using sports and war metaphors, 
which reflect the features of people's experience, thinking and vision. Most probably, speakers of one language sometimes find it difficult to appreciate the metaphors of another language. This is because "communication is based on the same conceptual system that we use in thinking and acting" (Lakoff and Johnson 1980:118).

Thus, sports metaphors make part of the American conceptual system, their mode of thinking and can help to shed light on the processes going on in their electoral system, where one side seeks to defeat the other. Moreover, sports metaphors can function to create an image of game in politics like they first have to run for and win the office in election, to play and score points in political or legislature games and fight the opposition while in office. In short, these metaphors are deeply rooted in American culture and appeal widely to the American electorate.

Sport metaphors overlap, to some extent, with WAR schemas, for war terminology is commonly resorted to talk about sports in English. Let's consider some examples from US president Donald Trump's speech in order to put this in perspective:

I think beating Obama would have been a much easier one than the one that's coming up, which is sad to say but true.

$$
\text { (<https://bit.ly/2YMW1JU>) }
$$

When politicians compete, they beat each other, as it is seen in the above mentioned example. Beating the adversary is common in games and sports matches, where one team beats the other and eventually gains the victory, therefore Trump takes up the verb beat to show his brutal and unexpected victory over ex-president Obama, although he never actually competed with him, thus putting Obama down by claiming that it would be easier to beat him than the candidates whom he will face in the future. Yet, in another example, Trump uses the word run speaking about a candidate who tried to get a government office, that of the president presumably, but failed. What's more, 
Trump or probably his speechmakers, intentionally or unintentionally, repeat the final word failed, thus intensifying the intended effect.

It' can't be Mitt because Mitt ran and failed. He failed.

$$
\text { (<https://nym.ag/2YPxRyz }>\text { ) }
$$

Presidential elections have always been compared with a race, i.e. presidents run and they either succeed or fail. That is why, president Trump in one of his presidential campaign speeches made the adduced remark about Mitt Romney, who had failed over again and who promised not to run against Trump in 2020 elections.

To further elaborate on the American way of thinking and the conceptual basis of their metaphoric expressions, let's look at a few more examples taken from president Trump's speeches, where he addresses a number of topics ranging from domestic issues to American overseas policies.

(1) Iran is taking over Iraq, and they're taking it over big league.

$$
\text { (<https://bit.ly/2HIdE83 }>)
$$

(2) We need a leader that can bring back our jobs, can bring back our manufacturing, canbring back our military, can take care of our vets.

$(<$ https://wapo.st/2KafSif $>)$

In the first example president Trump uses the phrasal verb take over, which is often used in sports games, such as soccer, when one player takes over the ball from another player. Besides, it should be noted in the first excerpt, although it is about a serious international conflict, the president employs the overly colloquial or rather slangish term big league, which other than having some explicit references to the sports leagues, has also the meaning of ignoring or doing something beyond good according to online Urban Dictionary, this brings the context closer to the everyday life and a layperson's repertoire of 
words, who, we earlier mentioned, is interested in politics as well as sports. Examining the second example we may encounter some difficulties. At first, one may not see a sport metaphor here, but going deeper into the sports studies we have found that the term bring back is widely used in basketball and means the action of bringing back the ball which was stolen by the opponent, which is the case in our example. President Trump uses this metaphor to show his ability, keenness, and alacrity to bring back everything which belongs to the proud American nation and which has been stolen from them. Hence, we can say that intranational conflicts are assimilated to (basket) ball games.

Nobody, nobody will be pushing us around.

$$
\text { (<https://wapo.st/2HHxqk5>) }
$$

This example is also taken from one of Donald Trump's 2016 presidential campaign speeches. Once more these examples state that sports metaphors are widely used in politics and are great means of conveying thought. Namely, the word loser or losing is used to define those teams that have lost the game, pushing around can refer to those players who are incompetently hurled around by other players in contact games, and game changer is applicable to those players who change the course of the game in favor of their team after entering the game. Thus again, politics is a GAME.

You know, when President Obama was elected, I said, "Well, the one thing, I think he'll do well. I think he'll be a great cheerleader for the country." (...) I really thought that he would be a great cheerleader. He's not a leader. (...) But he wasn't a cheerleader. He's actually a negative force.'

$$
\text { (<https://bit.ly/30M8K1i }>\text { ) }
$$

Not only does this excerpt from one of Trump's speeches make it obvious that Trump's biggest rival, his biggest problem is Obama, but it also proves Trump's incontinence towards the previous President. Trump diminishes 
Obama's political competence by downgrading him from a leader to a cheerleader, which is a term typically used in relation to a female college student who leads a team of similar female students, who perform gymnastic dances and songs, before and after athletic games, in order to cheer and support their team of athletes. In the next example, Trump repeatedly uses the phrasal verb kick in yet another term that would usually appear in sports contexts.

You look at Obamacare. A total catastrophe and by the way it really kicks in in'16 and it is going to be a disaster.But Obamacare kicks in in 2016. Really big league.

$$
(<\text { https://bit.ly/2IkPm5m>) }
$$

He uses kick in to qualify the process of a legislation taking effect. This sounds rather brusque and conveys some negative connotations about this legislation and shows the speaker's disapproval of it.

Below, let's discuss some other examples taken from 2019 presidential campaign speeches:

$$
\begin{aligned}
& \text { In our National Security Strategy that the President } \\
& \text { Trump released last December, he described a new era } \\
& \text { of "great power competition." } \\
& \qquad(<\mathrm{https} / / / \text { bit.ly/2OCjmww }>)
\end{aligned}
$$

Politics has always been described as a game, and as usual a game is a kind of a competition. The above mentioned example by Vice President Pence clearly views the world of politics under the light of competition. Great powers here is associated with strong countries which in President Trump's words compete with each other.

(1) Brothers and sisters: We're going to win this election not because we have a super PAC funded by billionaires. 
(2) Let's be honest: while we have won some victories, our struggles have not always been successful.

(<https://bit.ly/2wz97P7>)

Bernie Sanders in his campaign speech again compares politics with a game, a game that needs to be won. In this example presidential election is considered to be a game that needs to be won.

\section{(..) It was a bruising race. But we kept coming back to} that basic point that I made in every speech.

$$
\text { (<https://politi.co/2wnAM5r }>\text { ) }
$$

Rick Santorum speaks about the past elections he participated in. All the elections that America experienced were hard but he describes the last election he participated in as a race, a very hard to win race. Here again, we have an example of sports metaphor, showing competition and strong desire to win.

Concluding the instances of the usage of metaphorical sports terms in the speeches of a male representative of American political platform, let's move on and consider some examples taken from his counterpart female representative's speeches delivered around the same period of time for the same purpose.

For some reason or another it was quite difficult for us to find sports metaphors in Hillary Clinton's speeches. However we succeeded to find some. In her 2016 concession speech Clinton notes that politics is a game and there is a loser and a winner. She represents herself as a loser in a particular game, i.e. when she lost elections, but she claims herself to be a winner by nature for those who believed in her abilities and strength. And again, this way of thinking and formulating her ideas comes to prove that political activities are regarded as games and thus embedded in the consciousness of not only male but also female politicians. Further excerpts taken from Clinton's political speeches come to prove our hypothesis.

"We're going to start calling some good plays. We're going to go on offense as well as playing defense." (<https://politi.co/2wnHRmp >) 
The example is taken from Hillary Clinton's speech of 2008 Presidential Campaign. Here again, we clearly can differentiate sport metaphors such as good play, go on offence, play defense. In her presidential campaign launch speech she elucidated the real state of America, meaning that in the past America had some achievements, but now not. Lack of actions makes America stand in the same position for a long time, without moving forward.

\section{(1) (...) Our history has moved in that direction, thanks} to generations of Americans who refuse to give up or back down.

\section{(<https://bit.ly/1XEH75G $>)$}

(2) I hear you. I see you. And as your president, I will always have your back.

$$
\text { (<https://bit.ly/2JKHA5y }>\text { ) }
$$

Here also, it is quite easy to spot metaphors that are used in sports, mainly in basketball game such as move in a certain direction, give up, back down".As stated earlier many politicians compare presidential elections to a basketball game. As we see here, Clinton also considers her presidential elections a basketball game. The similarity of Clinton's conceptual thinking to that of her male counterparts, to that of Donald Trump in particular, could be explained by the fact that society tends to entrust important matters of governance to male representatives of the same society, who are thought to be guided more with logic and less with sentiments, tactics typical of sports as well as war. Therefore, Clinton's image makers might have tried to assimilate her political figure to that of a strong male politician, in order to gain more electorate confidence and bring about her political triumph. This, by no means, comes to refute the idea that women too can possess a competitive mind and see politics as sports or war, however, this hypothesis aims to put forward the idea that such a way of thinking is more typical of men politicians as displayed in the speeches of Donald Trump. 
Having analyzed 2019 presidential campaign speeches by different female candidates too, we found a lot more examples of sports metaphors widely used by women in politics. This example is taken from the Rachel Maddow Show, to be more precise, from the interview with Senator Kirsten Gillibrand. The interviewer Rachel Maddow begins her interview with sports metaphor running in this field, of course we should not take the literal meaning of this expression, however, both running and field are baseball related terms, which would most usually be used in situations where this game is involved.

Why is she running? Why is she running in this field?

How does she distinguish herself in this field?

(<https://on.msnbc.com/2K6RX3f $>$ )

Although the above-mentioned example is not from a politician's speech, it reflects the reality of how politics is conceived in the minds of those people who have to do with it; both as politicians as well as journalists who cover the formers' activities.

No wonder, politicians tend to use various conceptual metaphors in their presidential campaign speeches, it helps them make their speeches more persuasive, more intimate and closer to the hearts of the general masses.

By leveling the playing field, our democracy will thrive
and we will protect against the dysfunction that's
poisoning Washington now.

(<https://bit.ly/30OGo6u $>)$

In the above-presented excerpt, Sen. Kristin Gillibrand singles out her todo tasks using a very interesting sports related phrase - level the playing ground - which is a synonymous expression to the commonly used idiom level the playing field meaning to make a situation fair for everyone according to Merriam Webster online dictionary. This expression helps her get her message across in a vivid yet understandable manner to her supporters. 
The verbs to lose or to win highly refer to sports metaphors and are also widely used in political discourse. With the help of these verbs politics is represented as a game, and politicians are players who have just two alternatives: to lose or to win. This tactic is especially used in electoral speeches.

To be sure we've won and we've lost, but we've never stopped playing.

$$
\text { (<https://bit.ly/2MLbqpx >) }
$$

Interestingly enough Elizabeth Warren starts her speech with a story. Not a typical beginning for a campaign speech, indeed. Anyway, she embroiders a sports metaphor to the main part of her speech so skillfully, that it makes the reader imagine the vitality of electing her as a future President of the USA.

\section{(..) A product of a rigged system that props up the rich} and the powerful and kicks dirt on everyone else.

$$
\text { (<https://bit.ly/2wr3yC0 }>)
$$

In her speech she used the word rigged which we would often come across in such expressions as rigged games or competitions. Although, we are to perceive this as natural and typical, we have to look deeper into the consciousness of the perception of certain concepts and ways of thinking, peculiar to Americans to better justify the usage of such expressions related not only to sports but to other spheres of American life.

\section{Conclusion}

As a result of our analysis we came to the conclusion that politics is perceived as a game and politicians are seen as players. Moreover, political parties are seen as sports teams and political tactics are understood as sports tactics. All of this is embedded in political speeches of more or less esteemed politicians. Thus, politics, put metaphorically, is a game to win. Politicians fight and compete with their opponents in order to win an election. In other words, people frequently talk about politics in terms of sports: baseball, basketball, 
football, etc. It is so common that the word race is more often used than the term election campaign and the phrase running mate sounds far more familiar than that of someone's campaign partner.

\section{References:}

1. Beard, A.(2000) The Language of Politics, London: Routledge.

2. Glucksberg, S. (2001) Understanding Figurative Language: From Metaphors to Idioms, Oxford and New York: OUP.

3. Hiraga, M. K. (2005) Metaphor and Iconity: A Cognitive Approach to Analyzing Texts, New York, New York: Palgrave Macmillan.

4. Lakoff, G. (1993) The Contemporary Theory Of Metaphor, In Andrew Ortony (ed.), Metaphor and Thought. London: Cambridge University Press

5. Lakoff, G. and Johnson, M. (1980) Metaphors We Live By, Chicago: University of Chicago Press.

6. Semino, E. (2008) Metaphor in Discourse, Cambridge and New York: CUP.

\section{Sources of Data:}

1. Interview with Senator Kristen Gillibrand. Available at: <http://www.msnbc.com/transcripts/rachel-maddow-show/2019-01-16?fb clid=IwAR15Nm9Uff9T504UYldufceoFCIIvbKCzKYzVnLkRSnzsyEXGSw FmarRkbw > [Accessed May 2019].

2. Remarks by Vice President Pence at the 2019 Munich Security Conference. Available at: <https:/www.whitehouse.gov/briefings-statements/remarksvice-president-pence-2019-munich-security-conference-munich-germa ny/> [Accessed May 2019].

3. Senator Bernie Sander's Presidential Campaign Speech. Available at: $<$ https://vtdigger.org/2019/03/02/full-text-sen-bernie-sanders-2020presidential-campaign-kickoff-speech/> [Accessed March 2019].

4. Rick Santorum Values Voter Summit speech. Available at: <https:/www.politico.com/story/2012/09/rick-santorum-values-votersummit-speech-transcript-full-text-081256>[Accessed March 2019]. 
5. Kamala Harris kicks off presidential campaign in Oakland. Available at: <http:/www.ktvu.com/news/transcript-kamala-harris-kicks-offpresidential-campaign-in-oakland > [Accessed March 2019].

6. Elizabeth Warren's 2020 announcement speech. Available at: <https:/www.masslive.com/politics/2019/02/read-elizabeth-warrens-2020announcement-speech.html> [Accessed March 2019].

7. President Trump's Campaign Launch Speech. Available at: <https://www.washingtonpost.com/news/the-fix/wp/2017/06/16/theyre-ra pists-presidents-trump-campaign-launch-speech-two-years-laterannotated/?noredirect=on\&utm_term=.8e5da9ac2ce8> [Accessed March 2019].

8. Hillary Clinton to Women and Girls: "Nothing Has Made Me Prouder Than to Be Your Champion”. Available at: <https://www.vogue.com/ article/hillary-clinton-concession-speech> [Accessed March 2019].

9. Hillary Clinton Campaign Rally Speech. Available at: <https://www.politico.com/story/2015/06/hillary-clinton-campaign-rallyspeech-transcript-118973> [Accessed March 2019].

10. Donald Trump Iowa Freedom Summit Speech. Available at: <http://www.p2016.org/photos15/summit/trump012415spt.html> [Accessed March 2019].

11. Clinton's Historic Victory Speech as Presumptive Democratic Nominee. Available at: <http://time.com/4361099/hillary-clinton-nominee-speechtranscript/>[Accessed March 2019].

12. Hillary Clinton's June 7 Victory Speech. Available at: <https://bluenationre view.com/full-transcript-of-hillary-clintons-june-7-victory-speech/> [Accessed March 2019].

13. Urban Dictionary. Available at: <www.urbandictionary.com $>$ [Accessed March 2019].

14. Merriam Webster's Advanced Learners' Dictionary. Available at: <https://www.merriam-webster.com> [Accessed March 2019]. 


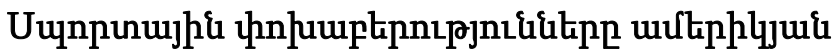

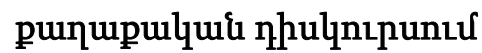

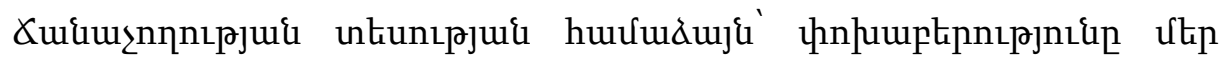

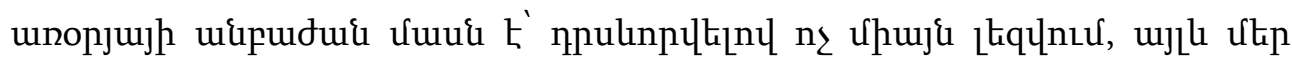

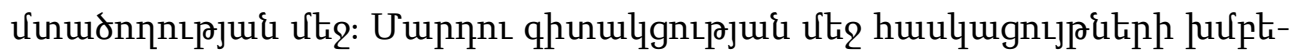

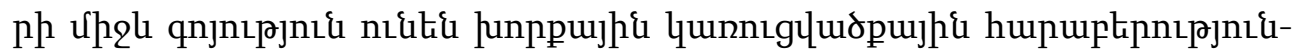

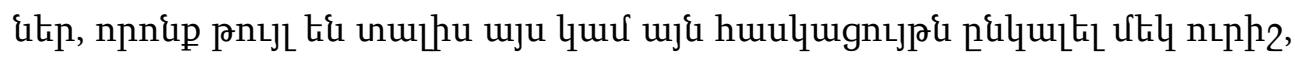

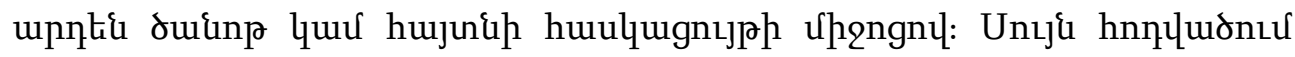

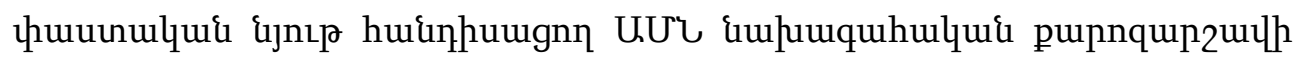

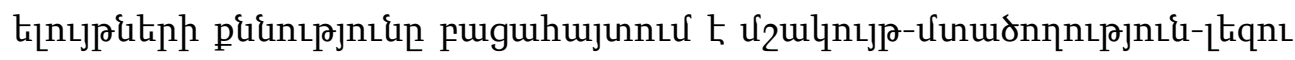

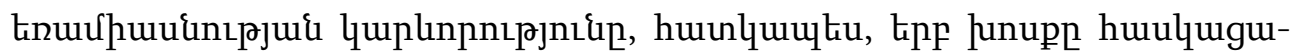

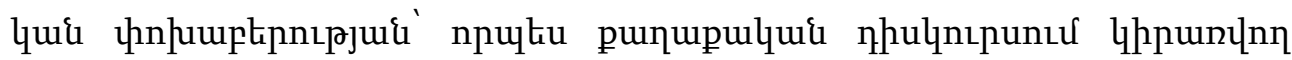

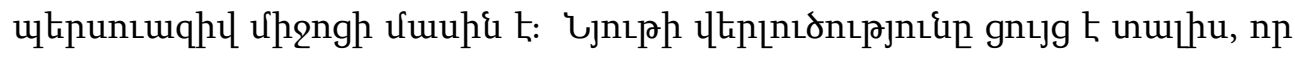

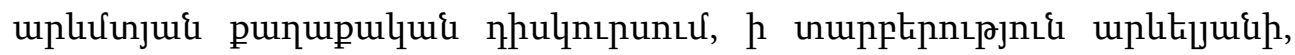

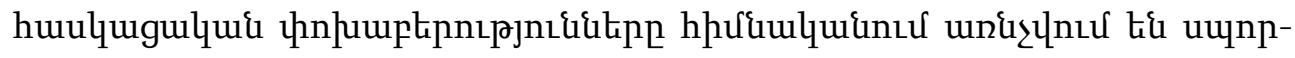

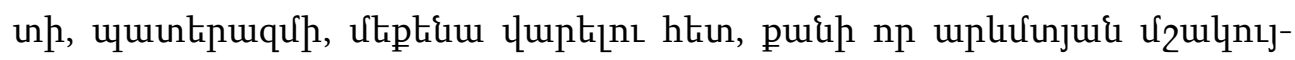

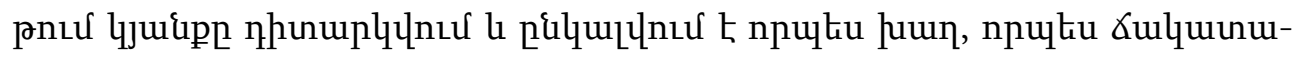
umpun, npulku unguruqp:

Received by the Editorial Board 01.02.2019

Recommended for publication by the reviewers 02.04.2019

Accepted for print 22.04.2019 